\title{
Further Studies on Classification of Bovine Strains of Mycoplasmatales, with Proposals for New Species, Acholeplasma modicum and Mycoplasma alkalescens
}

\author{
By R. H. LEACH \\ Mycoplasma Reference Laboratory, Central Public Health Laboratory, \\ Colindale Avenue, London, $\mathrm{NW}_{9}{ }_{5} \mathrm{HT}$
}

(Received 7 August 1972; revised 6 November 1972)

\begin{abstract}
SUMMARY
The eight groups of bovine Mycoplasmatales previously studied were confirmed as serologically different from each other. In addition, group 4 (Mycoplasma bovirhinis) and the unnamed groups 6,7 and 8 were found to be antigenically distinct from 34 other recognized species. Mycoplasma bovirhinis is thus verified as an independent species and, on the basis of their known serological and biochemical characters, two of the three unnamed groups are proposed as new species, Acholeplasma modicum (group 6) and $M$. alkalescens (group 8); the naming of group 7 is withheld because of uncertainties regarding its taxonomic status in relation to $M$. mycoides. Group 5 was distinct from all species except M.agalactiae, with which it shares biochemical and some antigenic characters, and its provisional name $M$. agalactiae subsp. bovis is therefore confirmed, and formally proposed, as appropriate for this group. Revised biological characters are noted for some bovine species; in particular the question of glucose fermentation by $M$. bovigenitalium and $M$. agalactiae subsp. bovis is re-assessed. The current general situation regarding classification of Mycoplasmatales species from cattle is discussed and an up-to-date list of named species and their type strains is presented.
\end{abstract}

\section{INTRODUCTION}

The classification scheme for bovine mycoplasmas suggested by Leach (1967) was based upon a comparison of some 40 strains which were divided into eight distinct serological groups, each with consistent biological characters. Three groups represented recognized species, viz. Mycoplasma mycoides subsp. mycoides, $M$. bovigenitalium and $M$. laidlawii (now Acholeplasma laidlawii; Edward \& Freundt, 1970); the name M. bovirhinis was suggested for the fourth group; the fifth contained a strain originally designated $M$. agalactiae var. bovis (Hale, Helmboldt, Plastridge \& Stula, 1962); groups 6, 7 and 8 were left unnamed. Three additional mycoplasmas have since been recognized amongst strains isolated from cattle, viz. M. dispar (Gourlay \& Leach, 1970), M. arginini (Leach, 1970) originally detected in sheep and goats (Barile, Del Giudice, Carski, Gibbs \& Morris, I968) - and M. oculi (Langford \& Leach, 1973).

The eight bovine groups were originally compared only with each other and not with mycoplasmas from other sources (Leach, 1967). However, although these organisms tend to be relatively host-specific, this property should not be given special weight for taxonomic purposes (Edward \& Freundt, 1969), as emphasized by recent examples of individual species found in quite different hosts (Taylor-Robinson \& Dinter, 1968; Tully \& Razin, 
1968; Leach, 1970; Armstrong, Yu, Yagoda \& Kagnoff, I97I; Tully, Del Giudice \& Barile, 1972). Therefore in order to complete a proper taxonomic description of bovine groups 4 to 8 , representative strains of each have been compared serologically with all available named species, irrespective of habitat, and the relevant morphological, physical and cultural characteristics (Subcommittee, 1972) of the unnamed groups 6, 7 and 8 have also been determined. In addition, certain other biological characters of bovine Mycoplasmatales species have been re-examined.

\section{METHODS}

Mycoplasma strains. Strains representing bovine groups I to 8 were either the type strains of recognized species (groups I to 3 ) or the provisionally designated type strains of the other groups, 4 to 8 (Cottew \& Leach, 1969). They came from the collection of Dr D. G. ff. Edward, Wellcome Research Laboratories, Beckenham, Kent, have now been deposited in the National Collection of Type Cultures (see Table 6) and were: Group I. Mycoplasma mycoides subsp. mycoides, strain PGI; Group 2. Mycoplasma bovigenitalium, strain PGII (B2); Group 3. Acholeplasma laidlawii, strain PG8 (Sewage A); Group 4. Mycoplasma bovirhinis, strain PG43 (5M33 I); Group 5. 'Mycoplasma agalactiae var. bovis', strain Donetta (PG45); Group 6. Unnamed, strain Squire (PG49); Group 7. Unnamed, strain N29 (PG50); Group 8. Unnamed, strain DI 2 (PG5I).

The type strain PG2 of Mycoplasma agalactiae (a species found in sheep and goats) was obtained from the same source. Details of other strains examined are given in the course of the paper. All reference strains had been 'cloned' by picking from a single colony at least once before use.

Antisera. The hyper-immune rabbit antisera against the eight bovine groups used in most serological studies, including the metabolic tests, were those prepared for a previous investigation (Leach, 1967), except for antisera to Mycoplasma mycoides subsp. mycoides, $M$. bovigenitalium and Acholeplasma laidlawii which were obtained from Dr Ruth Lemcke (Lemcke, 1964) and were used in these tests because they were more potent than other available antisera for these species. The antisera had been prepared against the representative bovine strains listed above, except that for M. mycoides subsp. mycoides which had been prepared against strain PP (Lemcke, 1964). For some tests by the growth inhibition method, the antisera used to represent $A$. laidlawii and $M$. bovirhinis were those of the Mycoplasma Reference Laboratory, prepared as described by Langford \& Leach, (I973).

Rabbit antisera prepared against the strains listed in Table I were obtained from laboratories or individual workers indicated there.

Media and cultural conditions. All the strains examined were grown in air in the fluid or solid media of Hayflick (1965): Bacto PPLO Broth (w/o C.V.) or Agar (Difco) supplemented with $20 \%(\mathrm{v} / \mathrm{v})$ unheated horse serum and $10 \%(\mathrm{v} / \mathrm{v})$ of a $25 \%(\mathrm{w} / \mathrm{v})$ aqueous boiled yeast extract, in addition to benzyl penicillin (200 to $1000 \mathrm{i} . \mathrm{u} . / \mathrm{ml})$ and thallous acetate $(0.025 \%, \mathrm{w} / \mathrm{v})$. These media were modified for special purposes as indicated below. Cultures were incubated at $37^{\circ} \mathrm{C}$, except when testing growth at $22{ }^{\circ} \mathrm{C}$. Agar plate cultures were incubated in plastic bags to prevent loss of moisture by evaporation.

Serological tests. Filter paper disc growth inhibition tests were performed by the method of Clyde (1964). Metabolic inhibition tests were carried out using 'Microtiter' apparatus, essentially as described by Taylor-Robinson, Purcell, Wong \& Chanock (I966) for strains causing acidification of glucose-broth and by Purcell, Taylor-Robinson, Wong \& Chanock (I966) for arginine-hydrolysing strains. The appropriate metabolite was added to the 
Table I. Antisera used in metabolic inhibition tests

Antiserum prepared against

\begin{tabular}{|c|c|c|c|}
\hline $\begin{array}{l}\quad \text { Species } \\
\text { Mycoplasma arginini } \\
\text { M. oculi } \\
\text { M. granularum }\end{array}$ & $\begin{array}{l}\text { Strain } \\
\text { G230 } \\
\text { M165/69 } \\
\text { BTs39 }\end{array}$ & Type of serum & Mycoplasma Reference Laboratory, Colindale \\
\hline$M$. orale type 2 & $\mathrm{CH} 20247$ & Rabbit & $\begin{array}{l}\text { Standards Laboratory for Serological Reagents, } \\
\text { Colindale }\end{array}$ \\
\hline $\begin{array}{l}\text { M. iners } \\
M . \text { meleagridis } \\
M . \text { anatis }\end{array}$ & $\begin{array}{l}\text { PG30 } \\
17529 \\
1340\end{array}$ & Donkey & N.I.H. Research Reference Reagent* \\
\hline M. axanthum & BIO7PA & Rabbit & $\begin{array}{l}\text { H. Ernø, Mycoplasma Reference Centre, } \\
\text { Aarhus, Denmark }\end{array}$ \\
\hline $\begin{array}{l}\text { M. agalactiae } \\
M . \text { mycoides subsp. capri } \\
M . \text { canis } \\
M . \text { pneumoniae } \\
M . \text { salivarium } \\
\text { M. orale type I } \\
M . \text { hominis } \\
M . \text { fermentans } \\
M . \text { gallisepticum } \\
M . \text { synoviae } \\
M . \text { arthritidis } \\
M . \text { hyorhinis }\end{array}$ & $\begin{array}{l}\text { PG2 } \\
\text { PG3 } \\
\text { PG14 } \\
\text { FH } \\
\text { PG20 } \\
\text { Hilverda } \\
\text { PG2 I } \\
\text { PG1 } 8 \\
\text { X95 } \\
\text { Lasswade } \\
\text { Preston } \\
\text { GDL }\end{array}$ & Rabbit & The present author ${ }^{\dagger}$ \\
\hline $\begin{array}{l}\text { M. agalactiae } \\
M . \text { primatum } \\
M . \text { gallinarum } \\
M . \text { pulmonis } \\
M . \text { neurolyticum }\end{array}$ & $\begin{array}{l}\text { Agalactia } \\
\text { Navel } \\
\text { Fowl } \\
\text { Kon } \\
\text { KSA }\end{array}$ & Rabbit & R. M. Lemcke, Lister Institute, London \\
\hline $\begin{array}{l}M . \text { hyosynoviae } \\
M . \text { maculosum } \\
M . \text { gateae }\end{array}$ & $\begin{array}{l}\text { A40 } \\
\text { PGI } 5 \\
\text { CS }\end{array}$ & Rabbit & $\begin{array}{l}\text { M. Goiš, Veterinary Research Institute, Brno, } \\
\text { Czechoslovakia }\end{array}$ \\
\hline $\begin{array}{l}\text { M. spumans } \\
\text { M. felis }\end{array}$ & $\begin{array}{l}\text { PGI } 3 \\
\text { Co }\end{array}$ & Rabbit & $\begin{array}{l}\text { D. G. ff. Edward, Public Health Laboratory, } \\
\text { County Hall, London }\end{array}$ \\
\hline M. suipneumoniae & $\mathbf{J}$ & Rabbit & $\begin{array}{l}\text { P. Whittlestone, School of Veterinary Medicine, } \\
\text { Cambridge }\end{array}$ \\
\hline M. dispar & $462 / 2$ & Rabbit & $\begin{array}{l}\text { R. N. Gourlay, Institute for Research on Animal } \\
\text { Diseases, Compton, Berkshire }\end{array}$ \\
\hline
\end{tabular}

* Mycoplasma reference antisera from the National Institutes of Health, Bethesda, Maryland, U.S.A.; received with the help of D. G. ff. Edward.

$\dagger$ Antisera prepared previously by the author at the Wellcome Research Laboratories, Beckenham, Kent.

standard medium as indicated below for biochemical tests. Fresh guinea-pig serum ( 3 to $6 \%, \mathrm{v} / \mathrm{v}$ ) was included in the medium, except for a few cases in which homologous titres of some of the antisera listed in Table I (Mycoplasma oculi, M. maculosum, M. spumans, $M$. meleagridis and $M$. hyosynoviae) were determined. All antisera were diluted $\mathrm{I} / 5(\mathrm{v} / \mathrm{v})$ in standard fluid medium, heated at $56^{\circ} \mathrm{C}$ in a water-bath for 20 to $30 \mathrm{~min}$ and then stored at $-30{ }^{\circ} \mathrm{C}$.

Metabolic inhibition titres were normally recorded when an appreciable colour change, representing at least $0.5 \mathrm{pH}$ unit, had occurred in the wells containing the test strain without antiserum. With the rapidly growing strains PG8 (Acholeplasma laidlawii) and N29 (group 7), inhibition of colour change by antiserum was usually transient and its detection 
required some vigilance, so that titres for these organisms were often recorded before this degree of $\mathrm{pH}$ change had occurred.

Biochemical tests. Glucose fermentation and hydrolysis of arginine or urea were tested in the standard fluid medium with Phenol Red (usually nominally $0.003 \%$, w/v, depending on the batch of indicator) plus $\mathrm{I} \%(\mathrm{w} / \mathrm{v})$ glucose or arginine or $0 . \mathrm{I} \%(\mathrm{w} / \mathrm{v})$ urea. The glucose medium was adjusted to approximately $\mathrm{pH} 7 \cdot 8$; arginine and urea media were adjusted to approximately $\mathrm{pH}_{7 \cdot 2}$ and $6 \cdot 0$ respectively. Screw-capped $\frac{1}{4}$ oz (bijou) bottles containing $3 \mathrm{ml}$ of the test medium were inoculated with small blocks (approximately $5 \mathrm{~mm} \times 5 \mathrm{~mm}$ ) taken from actively growing cultures on agar medium. A control inoculated with a block of sterile agar was included with each test. A rise in $\mathrm{pH}$ in arginine or urea medium, or a fall in $\mathrm{pH}$ in glucose medium, of 0.5 unit or greater was provisionally positive, subject to confirmation by a repeat test with the additional control of inoculated medium of the same initial $\mathrm{pH}$ but without the test metabolite.

Ability to reduce tetrazolium salt aerobically was tested by a method similar to that of Kraybill \& Crawford (1965). An agar block from a dense actively growing culture on solid medium was inverted, but not spread, on a plate of standard agar medium incorporating $0.02 \%(\mathrm{w} / \mathrm{v}) 2,3,5$-triphenyl tetrazolium chloride. The test plate was incubated aerobically for up to one week and the development of a pink or red colour beneath the inoculated block constituted a positive reaction.

Tests for other biological properties. The ability to grow in medium without serum was tested by inoculation of an agar block from an actively growing culture on standard horse serum agar on to serum-free agar. If growth was observed during Io days of incubation, further subcultures on serum-free agar were made. Strains that failed to survive three subcultures on this medium were recorded as serum-dependent; those showing growth at the third subculture were recorded as serum-independent and this result was confirmed by carrying the strain through a total of at least ten subcultures on serum-free agar.

Inhibition of growth by sodium polyanethol sulphonate (SPS; 'Liquoid' - Roche Products Ltd, Welwyn Garden City, Hertfordshire) was tested using filter paper discs wetted with $5 \%(\mathrm{w} / \mathrm{v})$ aqueous SPS solution (Kunze, I97I). Negative tests were checked with discs wetted with $10 \%$ and $20 \%$ (w/v) SPS.

Growth at $22{ }^{\circ} \mathrm{C}$ was accepted as positive after two serial subcultures on standard agar plates incubated for up to 2 weeks. The viability of the inoculum was checked at $37^{\circ} \mathrm{C}$.

Production of 'film and spots' (Edward, 1954) was tested on $20 \%$ horse serum agar plates incubated aerobically for 2 weeks and examined both macroscopically and microscopically.

Filtration characteristics. The filtrability of strains was examined by the Mycoplasma Reference Laboratory's routine method. Cultures in horse serum broth were filtered through nominal $450 \mathrm{~nm}$ Millipore membranes in Swinney-type adaptors attached to a hypodermic syringe operated manually with minimal pressure. The first $\mathrm{I} \mathrm{ml}$ was discarded and a further drop was plated on to standard agar medium. A hundredfold dilution of the unfiltered culture was also plated and comparison of the amount of growth obtained on each plate provided a rough estimate of the loss resulting from filtration.

Reversion tests. Seven serial subcultures were carried out at 2- to 3-day intervals in the standard solid or fluid medium without penicillin and thallous acetate. Five subcultures were on solid medium, followed by one in fluid medium, which was then plated on the solid medium and on blood agar. Growth was examined after each subculture in order to determine the absence of bacterial colonies and to check the colonial morphology. 

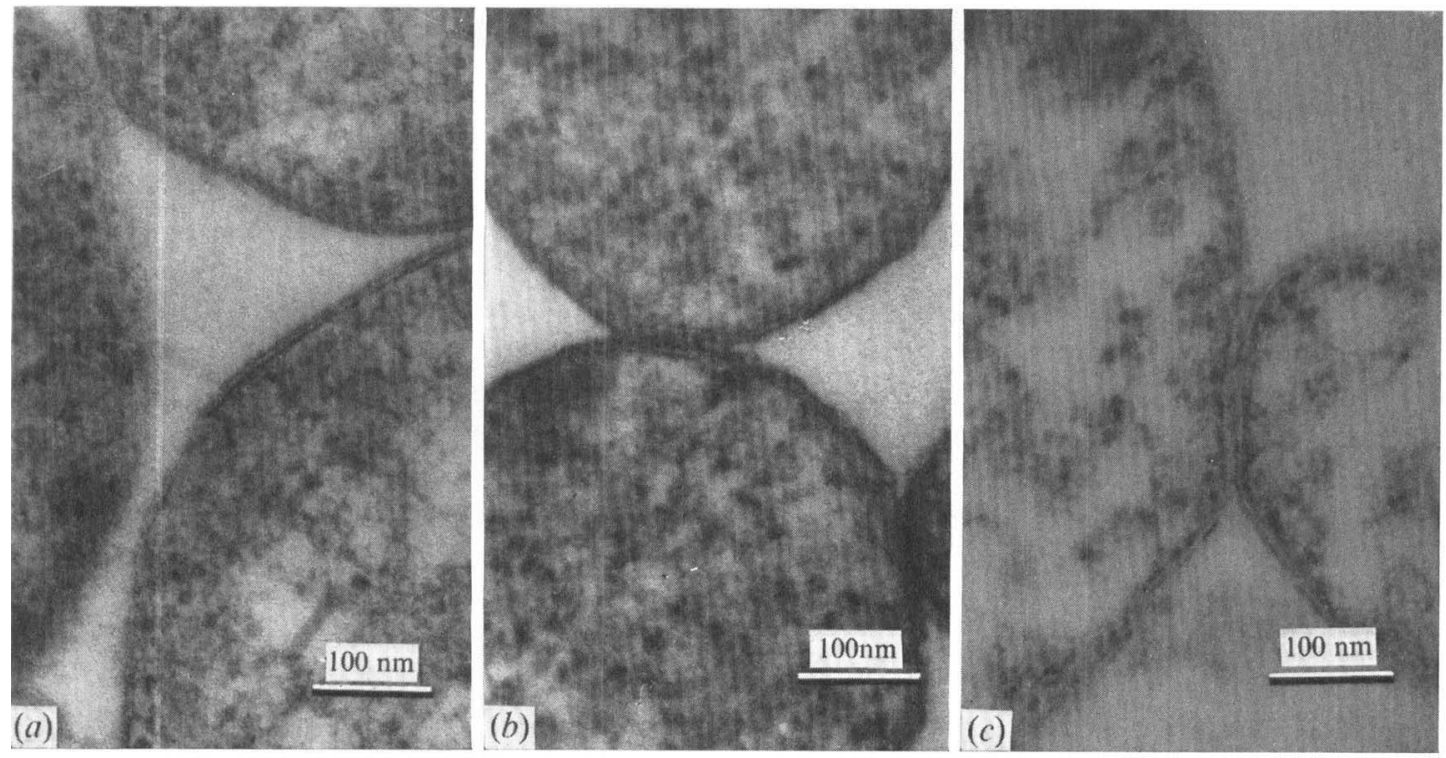

Fig. I. Electron micrographs of thin-section preparations of centrifuged culture deposits of bovine strains. (a) Group 6 strain Squire. (b) Group 7 strain N29. (c) Group 8 strain DI 2.

Films prepared from the final subcultures were examined microscopically after Gram and Giemsa staining to ensure absence of bacteria.

Electron microscopy. One hundred $\mathrm{ml}$ of a 2-day-old broth culture was centrifuged at I000 $\mathrm{g}$ for $\mathrm{I} \mathrm{h}$ in a $250 \mathrm{ml}$ centrifuge bottle in the swing-out head of an unrefrigerated centrifuge. The resulting deposit was resuspended in 5 to $10 \mathrm{ml}$ phosphate-buffered saline (PBS) at $\mathrm{pH} 7 \cdot 3$ and recentrifuged in a $15 \mathrm{ml}$ conical centrifuge tube at $1000 \mathrm{~g}$ for one hour. The deposit was resuspended in PBS and recentrifuged as before. The supernatant fluid was discarded and subsequent treatment was carried out by Mr F. G. Rodgers (Virus Reference Laboratory, Central Public Health Laboratory, Colindale), as follows.

Whole pellets were fixed at room temperature in $\mathrm{I} \%(\mathrm{v} / \mathrm{v})$ glutaraldehyde in cacodylate buffer $(\mathrm{CB})$ at $\mathrm{pH} 7.3$ for $20 \mathrm{~min}$, washed in $\mathrm{CB}$, and postfixed in $\mathrm{I} \%(\mathrm{v} / \mathrm{v}) \mathrm{OsO}_{4}$ in $\mathrm{CB}$ for $25 \mathrm{~min}$. During dehydration in a graded ethanol series, the pellets were cut into $0.5 \mathrm{~mm}$ cubes which were embedded in an epon-araldite mixture (Mollenhauer, 1964) and polymerized by heating at $60^{\circ} \mathrm{C}$ for $24 \mathrm{~h}$. The blocks were sectioned on a Reichert OmU2 ultramicrotome and the sections stained with uranyl acetate and lead citrate and examined in an AEI EM6B electron microscope.

\section{RESULTS}

General characteristics of groups 6,7 and 8

Strains Squire (group 6), N29 (group 7) and DI2 (group 8) were examined for microscopic colonial appearance, filtrability and certain other properties relevant to classification within the Mycoplasmatales (Subcommittee, I972).

Morphology and staining characteristics. Electron microscopy of thin-section preparations of Squire, N29 and DI 2 showed that these consisted of round organisms with diameters ranging between $200 \mathrm{~nm}$ and $900 \mathrm{~nm}$, although in the group 8 preparation the largest 
particles seen were only about $600 \mathrm{~nm}$ in diam. All three preparations also contained a small proportion of typical minute electron-dense forms, 50 to $150 \mathrm{~nm}$ in diameter. The intracellular structure included a network of filaments, visible throughout the larger particles, and numerous minute ribosome-like bodies that tended to be more concentrated in smaller particles. The organisms of each strain lacked a wall and were bounded only by a typical triple-layered membrane approximately Io $\mathrm{nm}$ in thickness (Fig. I).

The morphology of the three test strains was also studied by examination of stained films of broth culture deposits and colony-impression preparations. All three strains failed to retain Gram's stain (and stained poorly with the counterstain) but could be readily stained by modified Giemsa methods (Gourlay \& Leach, I970). In stained films each organism exhibited minute coccal or cocco-bacilliform particles, together with some 'ring' and other pleomorphic forms. The colony impression preparations were also similar in appearance to those of other mycoplasmas (Klieneberger-Nobel, 1962), showing a densely staining granular central area with a periphery containing larger and more pleomorphic forms.

Colonial appearance. Strains Squire, N29 and DI2 each produced a typical 'fried-egg' colony on the standard solid medium, with the centre of the colony penetrating into the agar. N29 (like other group 7 strains) grew much more rapidly and profusely in standard media than most other mycoplasmas. On agar it produced colonies greater than $0.5 \mathrm{~mm}$ in diam. after $48 \mathrm{~h}$ at $37^{\circ} \mathrm{C}$, while some exceeding $2 \mathrm{~mm}$ in diam. were seen after one week. In contrast, colonies of strain Squire were distinctly smaller after 2 to 3 days of incubation than those of Acholeplasma laidlawii or A. granularum, two other sterol-independent species with which it was directly compared.

Filtration tests. Broth cultures of Squire, N29 and DI 2 were each shown to pass through Millipore membranes of nominal pore diam. $450 \mathrm{~nm}$, with a loss which never exceeded a hundredfold in terms of colony count.

Reversion studies. Strains Squire, N29 and DI 2 all grew well in the presence of 1000 i.u. benzyl penicillin $/ \mathrm{ml}$ and $0.025 \%(\mathrm{w} / \mathrm{v})$ thallous acetate. In the absence of these inhibitors, they did not show any evidence (colonial, cultural and microscopical) of reversion to bacte rial forms (see Methods).

\section{Serological tests with groups i to 8}

Growth inhibition tests with the reference strains for groups I to 8 (see Methods) confirmed previous findings (Leach, 1967) that each group is quite distinct by this technique. Each of these strains was also tested by the metabolic inhibition technique against antisera to the other seven groups. Reciprocal titres of at least 1280 were recorded with homologous strains and there were no cross-reactions with heterologous organisms at titres greater than 20, a level regarded as insignificant or due to non-specific causes (Table 2).

In addition, the reference strains for groups 4 to 8 were tested by the metabolic inhibition technique against antisera to 3I other recognized species of Mycoplasmatales (Edward \& Freundt, 1973). Although all but two of these had homologous titres of at least 640, none reacted with the bovine strains at titres higher than 20 , except for one antiserum to Mycoplasma agalactiae (homologous titre $\geqslant 20000$ ) for which a titre of $\mathrm{I} / 80$ was recorded against the group 5 strain Donetta (Table 3). Many of the antisera listed in Table 3 were insufficiently potent for use in growth inhibition tests but those that were tested against any of the bovine reference strains gave negative results.

Antisera to three other mycoplasmas, Mycoplasma caviae, M. edwardii and M. conjunctivae, were not available but these three species, represented by strains PG24, GI22 and 


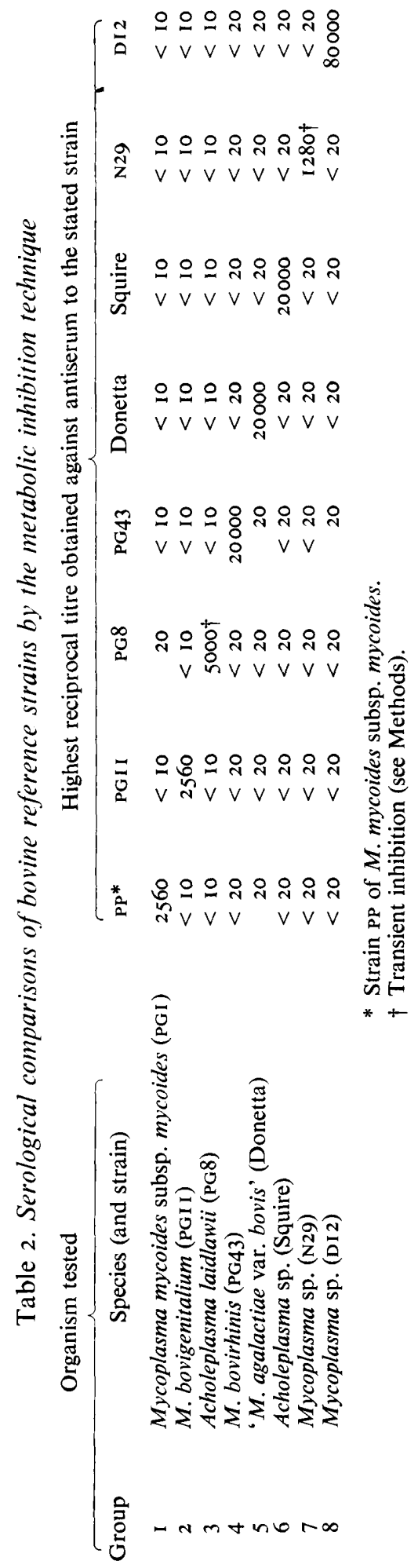


Table 3. Serological tests of bovine groups 4 to 8 against antisera to recognized species of Mycoplasmatales by the metabolic inhibition technique

Reciprocal titre against stated strains

Antisera to stated species*

Mycoplasma dispar

M. arginini

M. oculi

M. agalactiae $\ddagger$

$M$. mycoides subsp. capri

$M$. primatum

$M$. salivarium

M. pneumoniae

$M$. orale type I

$M$. orale type 2

$M$. hominis

M. fermentans

$M$. anatis

M. gallinarum

M. gallisepticum

$M$. iners

M. meleagridis

M. synoviae

M. arthritidis

$M$. neurolyticum

$M$. pulmonis

M. hyorhinis

$M$. hyosynoviae

M. suipneumoniae

M. canis

M. maculosum

M. spumans

M. felis

M. gateae

Acholeplasma axanthum

A. granularum
Strains representing bovine groups 4 to 8 respectively

\begin{tabular}{|c|c|c|c|c|c|}
\hline & & & & & \\
\hline Homologous $\dagger$ & PG43 & Donetta & N29 & Squire & DI 2 \\
\hline 640 & $<20$ & $<20$ & $<20$ & $<20$ & $<20$ \\
\hline$\geqslant 10000$ & $<20$ & $<20$ & $<20$ & $<20$ & $<20$ \\
\hline 2560 & $<20$ & $<20$ & $<20$ & $<20$ & $<20$ \\
\hline $1 \geqslant 20000$ & $<20$ & 80 & $<20$ & $<20$ & $<20$ \\
\hline 40000 & $<20$ & $<20$ & $<20$ & $<20$ & $<20$ \\
\hline 5000 & $<20$ & $<20$ & $<20$ & $<20$ & $<20$ \\
\hline 640 & $<20$ & $<20$ & $<20$ & $<20$ & $<20$ \\
\hline 640 & $<20$ & $<20$ & $<20$ & $<20$ & $<20$ \\
\hline 80 & $<20$ & $<20$ & $<20$ & $<20$ & $<20$ \\
\hline 1280 & $<20$ & $<20$ & $<20$ & $<20$ & $<20$ \\
\hline$\geqslant 5000$ & $<20$ & $<20$ & $<20$ & $<20$ & $<20$ \\
\hline$\geqslant 5000$ & $<20$ & $<20$ & $<20$ & $<20$ & $<20$ \\
\hline$\geqslant 5000$ & $<20$ & $<20$ & $<20$ & $<20$ & $<20$ \\
\hline$\geqslant 5000$ & $<20$ & $<20$ & $<20$ & $<20$ & $<20$ \\
\hline$\geqslant 5000$ & $<20$ & $<20$ & $<20$ & $<20$ & $<20$ \\
\hline$\geqslant 5000$ & $<20$ & $<20$ & $<20$ & $<20$ & $<20$ \\
\hline 2560 & $<20$ & $<20$ & $<20$ & $<20$ & $<20$ \\
\hline 640 & $<20$ & $<20$ & $<20$ & $<20$ & $<20$ \\
\hline I 280 & $<20$ & $<20$ & $<20$ & $<20$ & $<20$ \\
\hline$\geqslant 5000$ & $<20$ & $<20$ & $<20$ & $<20$ & $<20$ \\
\hline$\geqslant 5000$ & $<20$ & $<20$ & $<20$ & $<20$ & $<20$ \\
\hline$\geqslant 5000$ & $<20$ & $<20$ & $<20$ & $<20$ & $<20$ \\
\hline 20000 & $<20$ & $<20$ & $<20$ & $<20$ & $<20$ \\
\hline$\geqslant 10000$ & $<20$ & $<20$ & $<20$ & $<20$ & $<20$ \\
\hline 160 & $<20$ & $<20$ & $<20$ & $<20$ & $<20$ \\
\hline 5120 & 20 & $<20$ & 20 & $<20$ & $<20$ \\
\hline 5120 & $<20$ & $<20$ & $<20$ & $<20$ & $<20$ \\
\hline I 280 & $<20$ & $<20$ & $<20$ & $<20$ & $<20$ \\
\hline 2560 & $<20$ & $<20$ & $<20$ & $<20$ & $<20$ \\
\hline 5120 & $<20$ & $<20$ & $<20$ & $<20$ & $<20$ \\
\hline 640 & $<20$ & $<20$ & $<20$ & $<20$ & $<20$ \\
\hline 640 & $<20$ & $<20$ & $<20$ & $<20$ & 20 \\
\hline
\end{tabular}

* For strains see Table I.

+ The highest titre recorded against the homologous or other reference strain of the stated species.

$\ddagger$ Two M. agalactiae antisera tested - see Table 5 for details of results.

MI64/69 respectively, gave negative results in growth inhibition tests against potent antisera to bovine groups 4 to 8 . The same strains gave titres of $<20$ in metabolic inhibition tests with these antisera which all had homologous titres of at least 1280 .

\section{Biochemical and other biological characters of groups $\mathrm{I}$ to 8}

The principal characters of the eight bovine groups are shown in Table $4(a)$ and the three recently named bovine mycoplasma species are also included for comparison. The data refer to the type (or provisionally designated type) strain for each group, but also indicate where other strains of a group may give varying results. The information regarding groups I to 8 was obtained from a re-examination of such strains carried out since previous reports (Leach, 1967; Cottew \& Leach, 1969) and certain properties, viz. requirement for serum, growth at $22{ }^{\circ} \mathrm{C}$ and glucose fermentation differ from those listed formerly.

Serum and sterol requirements. Repeated testing confirmed that the strains representing 


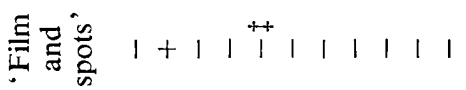
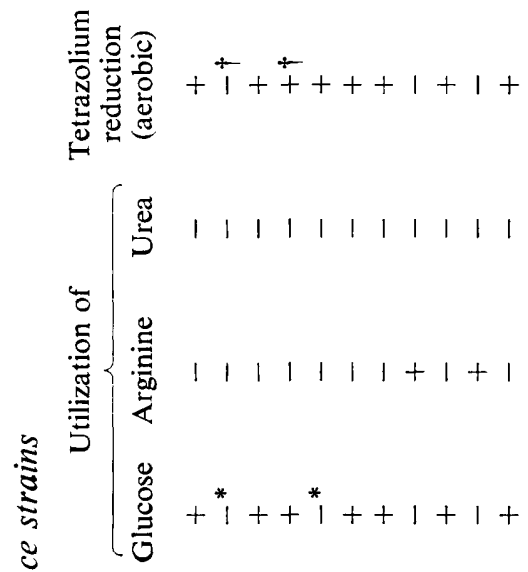

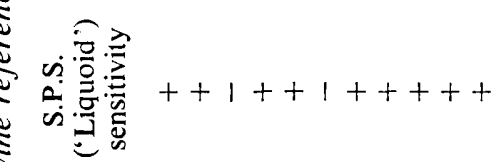

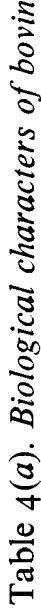

言总产 $++1++1+++++$

递 $11+11++11111$

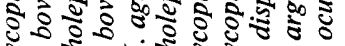

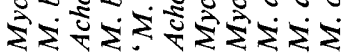

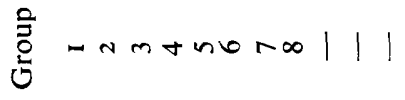

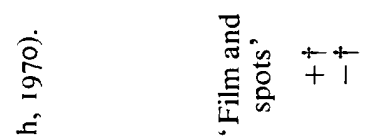

ळ

产

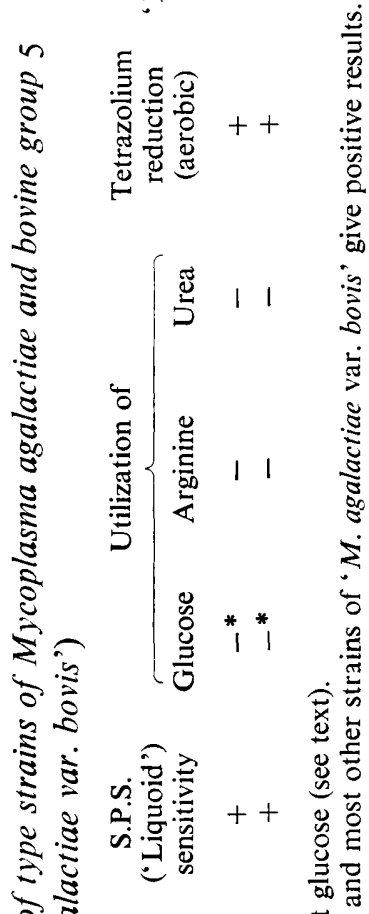

$+2$

过䒕

$\stackrel{\circ}{=}$

遇

产它

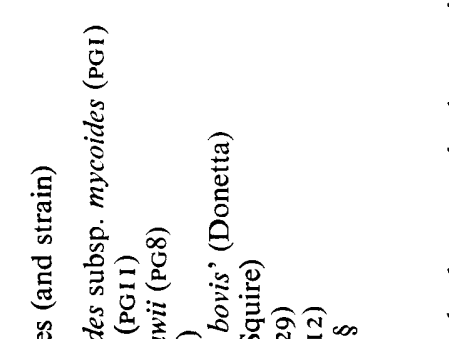

氙

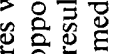

表它语

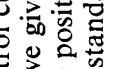

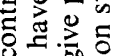

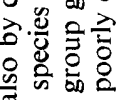

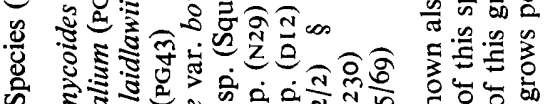

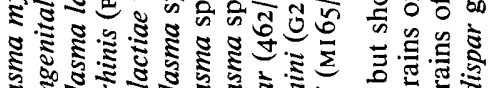

3.

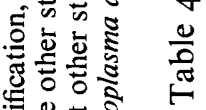

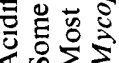

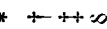

28

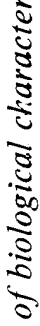

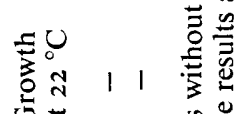

ปั

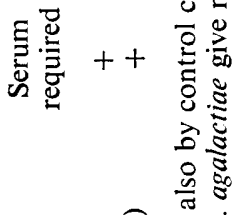

竎

官

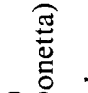

运

สูํำ

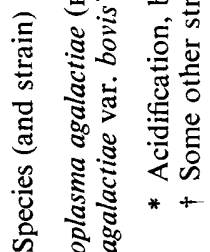

¿: 
bovine mycoplasma groups I, 2, 4, 5, 7 and 8 could not be maintained by serial subculture in the absence of serum (Table $4 a$ ). The group 7 strain $\mathrm{N} 29$, which grows profusely on standard media, usually produced some growth at the first or second subculture on serumfree agar, particularly around the agar block inoculum or in heavily inoculated areas, but no significant growth was obtained after the second subculture.

The group 3 strain PG8, as expected, grew readily on serum-free agar. The group 6 strain, Squire, grew slowly and produced smaller colonies in the absence of serum; however the serum-independence of the group, previously uncertain (Leach, 1967; Cottew \& Leach, 1969), was confirmed when Squire and another group 6 strain were each carried through at least ten serial subcultures on serum-free agar and also on medium without either serum or yeast extract. Edward (I97I) has shown that Squire will grow in sterol-free agar and this has been confirmed by J. G. Tully (personal communication) using sterol-free broth (Razin \& Tully, I970). J. G. Tully (personal communication) has also determined that this strain is negative in the test for pigmented carotenoids (Tully \& Razin, I968).

Like other sterol-independent strains (Andrews \& Kunze, I972), PG8 (group 3) and Squire (group 6) were resistant to concentrations of $5 \%$, $10 \%$ and $20 \%(\mathrm{w} / \mathrm{v})$ sodium polyanethol sulphonate (SPS), whereas the representatives of all the serum-dependent bovine mycoplasmas were inhibited by $5 \%$ SPS (Table $4 a$ ).

Growth at $22{ }^{\circ} \mathrm{C}$. The results of tests for growth at $22{ }^{\circ} \mathrm{C}$ (Table $4 a$ ) were similar to those previously recorded (Cottew \& Leach, 1969), except for group 7 (strain N29) which produced slow and relatively faint, but definite, growth on horse serum agar subcultured at approximately weekly intervals.

Glucose fermentation. The ability of strain PGI I (group 2) and strain Donetta (group 5) to ferment glucose was re-examined in detail. In $\mathrm{I} \%$ glucose broth medium incubated at $37{ }^{\circ} \mathrm{C}$, both strains showed an appreciable lowering of $\mathrm{pH}$ (usually $>0.5 \mathrm{pH}$ unit) as compared with uninoculated glucose broth. However, a similar fall in $\mathrm{pH}$ was obtained in inoculated medium of the same initial $\mathrm{pH}$ without glucose. Essentially the same results were obtained with medium lacking yeast extract and containing only $5 \%(\mathrm{v} / \mathrm{v})$ horse serum for tests with PGI I or I \% (v/v) horse serum for tests with Donetta. Each strain was taken through at least six serial subcultures in this medium both with and without glucose, but in neither case was there any enhancement in the amount of acidity produced, which remained approximately equal for a given strain in either medium. Thus, contrary to a previous report (Cottew \& Leach, I969), no evidence was obtained that either strain utilized glucose added to the medium.

The results of glucose fermentation tests on other strains (Table $4 a$ ) were as previously reported (Leach, I967; Cottew \& Leach, 1969).

\section{Comparison of group 5 strains with Mycoplasma agalactiae}

The properties of the type strain PG2 of Mycoplasma agalactiae were determined for comparison with those of group 5 strain Donetta. The two strains (Table $4 b$ ) were essentially identical, except in ability to produce 'film and spots', a test known to give varying results for different strains within each group. Donetta acidifies glucose medium in the absence of evidence for glucose fermentation (see preceding section) and the same phenomenon was observed with strain PG2, both findings having been confirmed by Edward \& Moore (1972).

In serological comparisons of bovine group 5 and Mycoplasma agalactiae, antisera against the group 5 strains Donetta, Palmer and Widanka inhibited all three strains in disc growth-inhibition tests, but failed to inhibit growth of $M$. agalactiae strain PG2. 


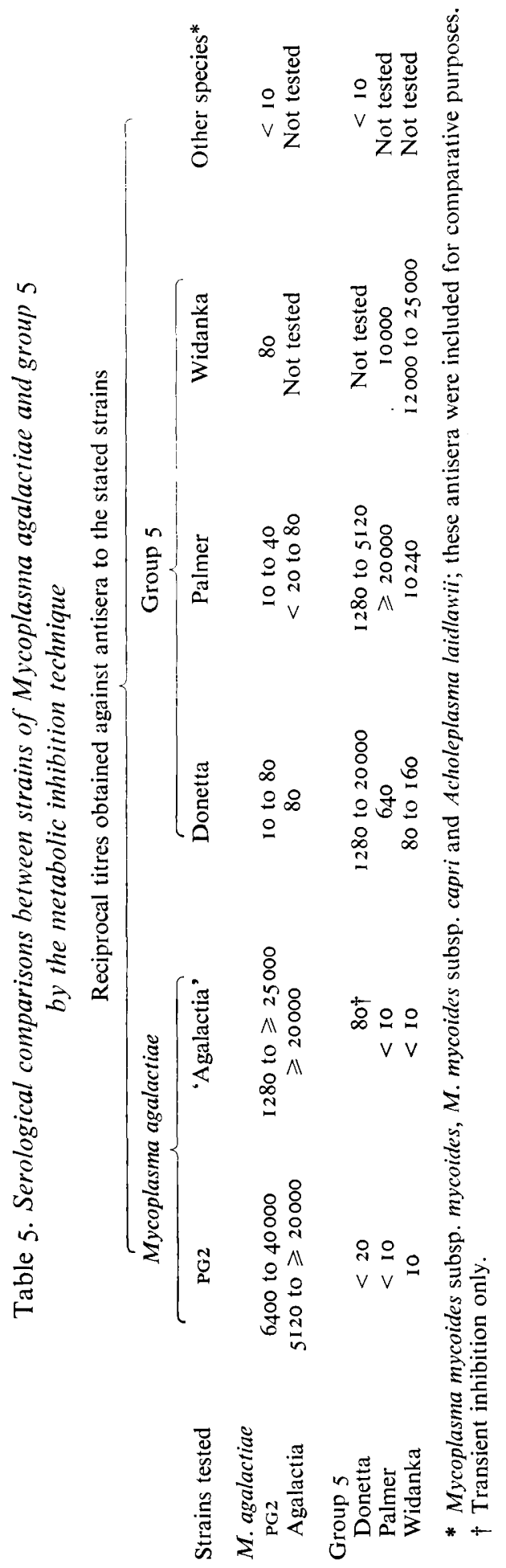


Reciprocal tests by this method could not be performed because the available antisera for $M$. agalactiae were insufficiently potent. However, virtually complete cross-testing was carried out by the metabolic inhibition technique (Table 5). Measurable metabolic inhibition reactions were obtained when the two $M$. agalactiae strains were tested against antisera to the three group 5 strains, although the titres recorded were variable and usually less than one-hundredth that obtained with the homologous strain. There was little evidence of cross-reactions in the other direction, but D. Taylor-Robinson (personal communication) using some of the same strains and antisera, has found some evidence for this, obtaining low-level cross-reactions in both directions between group 5 and M. agalactiae.

\section{DISCUSSION}

Bovine mycoplasmas were previously classified into eight groups (Leach, 1967) and the present results obtained with growth-inhibition and metabolic inhibition tests confirm that the reference strains for each group are serologically distinct. Al-Aubaidi \& Fabricant (I97I) have reported essentially similar findings. Three groups, Mycoplasma mycoides subsp. mycoides, M. bovigenitalium and Acholeplasma laidlawii, are well-established species (Edward \& Freundt, 1956; 1970; 1973) and need not be discussed further, but the taxonomic status and nomenclature of groups 4 to 8 can be reconsidered in the light of information presented in this paper.

Although the original descriptions of groups 4 (Mycoplasma bovirhinis) and 5 (" $M$. agalactiae var. bovis') were incomplete, they have been accepted (Edward \& Freundt, 1973) as belonging to the Mycoplasmatales. The unnamed groups 6, 7 and 8 have also been shown here to possess the properties defining this order (Subcommittee, 1972). Electron microscopy (Fig. I) indicated that organisms of strains Squire (group 6), N29 (group 7) and DI 2 (group 8) conformed with those of other members of the Mycoplasmatales in their size, shape, internal appearance and particularly in having a limiting membrane of characteristic appearance but no cell wall (Anderson, I969; Razin, I969; Horne, I970; Carstensen, Maniloff \& Einolf, I97I). The test strains examined by light microscopy had typical staining reactions and showed characteristic coccobacilliform and pleomorphic particles. They were filtrable at $450 \mathrm{~nm}$ without much loss of viability and their colonial appearance was of the usual 'fried-egg' type with downgrowth into the agar. Each was insusceptible to penicillin and did not revert to bacterial forms in media without anti-microbial agents. As with other mycoplasmas, their growth was inhibited by specific antiserum without complement. It therefore follows that groups 6,7 and 8 should be classified within the order Mycoplasmatales.

Regarding further classification of groups 4 to 8, the reference strains for each (see Methods) were distinct in growth inhibition and metabolic inhibition tests from each other and from 37 additional named species (or subspecies) of Mycoplasmatales (see Results), except that group 5 showed some cross-reactivity with Mycoplasma agalactiae (see below). These 37 species include virtually all those accepted as validly named members of the Mycoplasmatales (Edward \& Freundt, 1973) and it therefore follows that groups 4 to 8 each represent a distinct species, or subspecies (see below), within this order. The nomenclature for individual groups is discussed in the following sections.

Group 4. When originally designated as Mycoplasma bovirhinis, this group had been compared only with other bovine mycoplasmas (Leach, 1967), but it is now confirmed as an independent and serologically distinct species. Strain PG43 (5M33I) is designated the type strain of Mycoplasma bovirhinis (see also Edward \& Freundt, 1973). A culture of PG43 has been 
deposited in the National Collection of Type Cultures, London, where it is available as NCTC 10118.

Group 5. The three strains classified by Leach (1967) in group 5 included one for which the name Mycoplasma agalactiae var. bovis had been suggested (Hale et al. 1962). This strain, known as Donetta (Hirth, Plastridge \& Tourtellotte, 1967) or the Connecticut strain (Jain, Jasper \& Dellinger, 1967), was originally compared only with an avian mycoplasma and the name appeared to have been suggested for clinical rather than taxonomic reasons. Leach (1967) therefore questioned the classification of this organism as a subspecies of $M$. agalactiae and Jain et al. (1967), reporting further isolates of the group, suggested another name, $M$. bovimastitidis, although not claiming to present further taxonomic evidence on this issue.

The serological results obtained with Donetta and other group 5 strains do indicate some antigenic sharing with Mycoplasma agalactiae (Table 5) and not with any other species (Table 3). The relationship between $M$. agalactiae (PG2) and Donetta has been confirmed both serologically (D. Taylor-Robinson, see Results; H. Ernø, see Minutes, I97I) and by mycoplasma protein electrophoretic studies (Razin, I968). In addition, the two mycoplasmas have very similar DNA base ratios of 33 to $34 \% \mathrm{G}+\mathrm{C}$ (Neimark, 1970), and have essentially the same biochemical and biological characters (Table $4 b$ and Leach, I967; Cottew \& Leach, 1969; Minutes, I97I). Group 5 also shares with $M$. agalactiae (and $M$. bovigenitalium) the ability to produce marked acidity in broth cultures while apparently unable to ferment glucose (Edward \& Moore, 1972; see also Results and Discussion below), a property distinguishing them from other Mycoplasma species.

The above observations support contentions (Razin, I968; Minutes, 197I) that Donetta and similar strains do represent a subspecies of Mycoplasma agalactiae. I therefore formally propose that group 5 strains should be designated $M$. agalactiae subsp. bovis (after Hale et al. 1962), with type strain Donetta (as proposed also by Edward \& Freundt, 1973), and that the name $M$. bovimastitidis (Jain et al. 1967 ) be rejected. A culture of $M$. agalactiae subsp. bovis, strain Donetta, has been deposited in the National Collection of Type Cultures, London, where it is available as NCTC IOI3I.

Group 6. The demonstration that Squire and another group 6 strain can be maintained on serum-free medium (see Results) conforms with other observations that the group is sterol-independent (Edward, I971; J. G. Tully, see Results) and should therefore be classified within the family Acholeplasmataceae and genus Acholeplasma (Edward \& Freundt, 1970). Squire resembles the three recognized species of Acholeplasma, Acholeplasma laidlawii, A. granularum and A. axanthum (Edward \& Freundt, 1973), in its main biological characters (Table $4 a$ ), although, with $A$. axanthum, it differs from the first two acholeplasmas in giving a negative result in the carotenoid test (J. G. Tully, see Results; Tully \& Razin, 1968; 1970).

The present results show that Squire is antigenically distinct from the three named species of Acholeplasma (Tables 2, 3), and this has been confirmed by J. G. Tully (personal communication). Protein electrophoretic studies (J. G. Tully, personal communication; Zola, Baxendale \& Sayer, I970) also support this finding. It is therefore proposed that Squire and other group 6 strains, first described by Langer \& Carmichael (1963), be designated a new species, Acholeplasma modicum. The specific epithet ('modicum'; Latin adjective in the neuter meaning 'moderate') refers to its relatively restrained growth as compared with A. laidlawii. Strain Squire is designated the type strain of $A$. modicum and a culture has been deposited in the National Collection of Type Cultures, London, where it is available as NCTC IOI 34 . 
There was previously some uncertainty (see Leach, 1967; Cottew \& Leach, I969) about the bovine habitat of group 6 , since the original strains were cultivated only after initial passage in tissue cultures (Langer \& Carmichael, 1963). However, another strain has now been confirmed in this laboratory among mycoplasmas cultivated directly from cattle into cell-free media (Stipkovits, Bokori, Horváth \& Molnár, I970; Horváth, Bokori, Stipkovits \& Molnár, 197I).

Group 7. Reference strain N29 requires serum for growth (Table $4 a$ ) and is sensitive to sodium polyanethol sulphonate, properties consistent with its demonstrated requirement for sterol (Edward, I97I). Group 7 should therefore be classified within the sterol-dependent family Mycoplasmataceae and genus Mycoplasma (Edward \& Freundt, 1970).

The present serological findings support the previous observations of Leach (I967) and of Al-Aubaidi \& Fabricant (I97I) that group 7 is distinct from other bovine mycoplasmas. However Cottew (1970), examining recent isolates, observed reactions in growth inhibition tests between group 7 and some strains of Mycoplasma bovigenitalium (group 2) when using his own reference antisera for groups I to 8, though not with antisera obtained from this laboratory, and he suggested the possibility that group 7 might represent a subdivision of $M$. bovigenitalium. In addition, Ernø \& Jurmanová (1972) recently reported obtaining cross-reactions by several serological methods between group 7 strain N29 and the type strains of $M$. bovigenitalium, $M$. mycoides subsp. mycoides (group I) and $M$. mycoides subsp. capri. In this laboratory cross-reactions were not obtained with the type strains for any of these mycoplasmas (see present resuits) but reactions have sometimes been observed in growth inhibition or metabolic inhibition tests between wild strains of the two $M$. mycoides subspecies (not $M$. bovigenitalium) and group 7 antisera. The DNA base composition of $25.6 \% \mathrm{G}+\mathrm{C}$ for group 7 strain $\mathrm{N} 29$ (determined by the 'meltingpoint' method by Mr L. R. Hill, National Collection of Type Cultures, Central Public Health Laboratory, Colindale) does not distinguish it clearly from the above three mycoplasmas whose reported values lie within the range 24 to $30 \%$ (Neimark, I970). On the other hand the major biochemical reactions, and particularly the glucose and 'film and spot' reactions, clearly differentiate group 7 from $M$. bovigenitalium (Table $4 a$; see also Al-Aubaidi \& Fabricant, 197I) and, notwithstanding the possibility of minor serological cross-reactions, it is improbable that group 7 is related to $M$. bovigenitalium at the species level. The relation of group 7 to $M$. mycoides is less clear. Its biological properties (Table $4 a$ ) do not distinguish strain N29 from $M$. mycoides subsp. mycoides or $M$. mycoides subsp. capri and in fact recently reported evidence (Ernø \& Stipkovits, 1972) indicates that these three mycoplasmas may resemble each other, and differ from other species, in having the ability to liquefy inspissated serum (see also Edward, 1954; Edward \& Freundt, 1969). Group 7 strains resemble $M$. mycoides subsp. capri in their relatively luxuriant growth (see also Cottew, 1970) as compared with $M$. mycoides subsp. mycoides or any other bovine Mycoplasma species.

The present serological results (Tables 2 and 3) appear to distinguish group 7 (first described by Simmons \& Johnston, 1963) from any other named species of Mycoplasmatales. However, in view of the recent work of Ernø and co-workers reported above, some doubt remains about the exact relationship between group 7 and the two subspecies of Mycoplasma mycoides and the formal naming of this group is therefore postponed, pending further investigations to establish whether it should be regarded as a distinct species or as a subspecies of $M$. mycoides. A culture of group 7 strain $\mathrm{N}_{29} 9$ has been deposited in the National Collection of Type Cultures, London, where it is available as NCTC IOI33.

Group 8. Several strains of this group have been isolated from cattle (Hudson \& Etheridge, 
I963; Brookbanks, Carter \& Holland, 1969) and from commercial bovine serum (Barile \& Kern, I 97I ; M. F. Barile, personal communication), but only one, DI 2, has been studied in detail. With regard to its classification within the Mycoplasmatales, preliminary findings (R. H. Leach, unpublished observations) with the method of Edward (I97I) have indicated that DI 2 requires sterol for growth, a property that is consistent with its serum-dependence, inhibition by sodium polyanethol sulphonate and failure to grow at $22{ }^{\circ} \mathrm{C}$ (Table $4 a$ ) and that establishes group 8 as a member of the family Mycoplasmataceae and genus Mycoplasma (Edward \& Freundt, 1969).

The present serological results confirm that DI 2 is distinct from other bovine mycoplasmas (see also Leach, 1967; Cottew, 1970; Al-Aubaidi \& Fabricant, 197I) and also distinguish it from other recognized species of Mycoplasmatales (Table 3). It is therefore proposed that DI 2 and other group 8 strains, first described by Hudson \& Etheridge (1963), should be designated a new species, Mycoplasma alkalescens. The specific epithet refers to the alkaline reaction it produces in arginine-containing medium ('alkalescens'; Latinized participial adjective in the neuter, meaning 'alkali-making'). Strain DI 2 is designated the type strain of $M$. alkalescens and a culture has been deposited in the National Collection of Type Cultures, London, where it is available as NCTC IOI35.

The question of glucose breakdown by Mycoplasma bovigenitalium and M. agalactiae subsp. bovis has caused difficulties. These two mycoplasmas have generally been regarded as non-fermenters (Edward, 1954; Hale et al. 1962; Jain et al. 1967; Leach, 1967; Aluotto, Wittler, Williams \& Faber, I970; Al-Aubaidi \& Fabricant, 197I), but this was disputed by Cottew \& Leach (1969). Undoubtedly both $M$. bovigenitalium and $M$. agalactiae subsp. bovis, like $M$. agalactiae (subsp. agalactiae), produce appreciable acidity in glucose broth, but carefully controlled cultural tests (see Results and Edward \& Moore, 1972) have now established that this effect is independent of glucose and occurs equally in glucose-containing and glucose-free media. Moreover, Edward \& Moore (1972) have recently demonstrated by definitive biochemical studies that there is no detectable loss of glucose during incubation of media inoculated with dense suspensions of $M$. bovigenitalium or of either subspecies of $M$. agalactiae and it must therefore be concluded that these three organisms should be classed as glucose non-utilizing. The reason for the acidification they produce in broth, which is sufficiently marked for use in metabolic inhibition tests (Cole, Cahill, Wiley \& Ward, 1969; Taylor-Robinson, Martin-Bourgon, Wanatabe \& Addey, I97I ; Langford \& Leach, 1973), remains unknown and requires further investigation.

The original classification of bovine strains into the eight groups now recognized as separate species or subspecies was based on an examination of only 40 isolates (Leach, 1967). It is therefore of interest that, of some 200 additional strains examined at this laboratory, over $90 \%$ have been readily identifiable by growth inhibition or metabolic inhibition tests as one or other of these eight or of the three more recently recognized species (see Table 6). It seems likely that an even higher proportion might have been identified if examined in greater detail and this suggests that these eleven mycoplasmas and acholeplasmas constitute the majority of those likely to be isolated from cattle on currently available media for large-colony mycoplasmas. The biological characters of almost all identified strains conformed with those of the type strains (Table 4a). An up-to-date list of named bovine species and their type strains is given in Table 6. Purified cultures of each have been deposited in the National Collection of Type Cultures (Central Public Health Laboratory, London, N.W. 9) where they are available under the NCTC number shown in Table 6. This table does not include the bovine T-mycoplasmas (Gourlay, I968; TaylorRobinson, Williams \& Haig, 1968; Taylor-Robinson, Thomas \& Dawson, 1969; Gourlay, 
Table 6. List of currently recognized Mycoplasma and Acholeplasma species with a bovine habitat*

\begin{tabular}{|c|c|c|}
\hline Species & Type strain & NCTC no. \\
\hline Mycoplasma mycoides subsp. mycoides & PG I & 10114 \\
\hline M. bovigenitalium & PGII (B2) & 10122 \\
\hline Acholeplasma laidlawii & PG8 (Sewage A) & 10116 \\
\hline M. bovirhinis & PG43 (5M33I) & 10118 \\
\hline M. agalactiae subsp. bovis & Donetta (PG45) & IOI3I \\
\hline A. modicum & Squire (PG49) & 10134 \\
\hline Mycoplasma sp. (group 7) & N29 (PG50) & 10133 \\
\hline M. alkalescens & DI 2 (PG5I) & 10135 \\
\hline M. dispar & $462 / 2$ & 10125 \\
\hline M. arginini & G230 & 10129 \\
\hline M. oculi & MI $65 / 69$ & IOI4I \\
\hline
\end{tabular}

* Note: There is some evidence that another named species, A. axanthum (type strain s743; NCTC IOI38), may have a bovine habitat (J. G. Tully \& J. M. Al-Aubaidi, personal communications).

Mackenzie \& Cooper, 1970), which still await formal classification but whose ability to utilize urea differentiates them clearly from all other sterol-dependent mycoplasmas.

An alternative classification scheme for bovine mycoplasmas (Al-Aubaidi \& Fabricant, I97I) recognized I 3 distinct serological groups (referred to as 'serotypes'), designated by the letters A to M. However, these included the eight groups (listed in a different order) of Leach (1967) plus five others, most of which now appear to belong to named species associated with non-bovine sources or to one of the original eight groups (J. G. Tully, J. M. Al-Aubaidi \& H. Ernø, personal communications; R. H. Leach, unpublished observations). The existence of two essentially similar classification schemes for bovine mycoplasmas having different systems of nomenclature might have caused some confusion, but it is hoped that this will be avoided now that the main groups concerned have been formally named as species, each with a designated type strain, according to the rules of the International Code of Nomenclature of Bacteria. Most of Leach's (1967) numbered 'group' system and Al-Aubaidi \& Fabricant's ( I97I) alphabetical 'serotype' system can now be abandoned in favour of the correct species names.

I am indebted for their help to colleagues at the Central Public Health Laboratory, viz. Mr. F. G. Rodgers (Virus Reference Laboratory) who prepared, examined, photographed and helped to interpret the specimens for electron microscopy and $\mathrm{Mr} \mathrm{L}$. R. Hill (National Collection of Type Cultures) who carried out the DNA extraction and base composition estimation. I am also grateful to Dr D. G. ff. Edward, Dr D. Taylor-Robinson and Dr J. G. Tully, for permission to quote their unpublished findings in the Results section. The help of workers providing antisera for serological studies is also gratefully acknowledged.

Special thanks are due to Dr B. E. Andrews for considerable advice on many aspects of the paper and for numerous valuable consultations during the course of its preparation. I am also indebted to Dr D. G. ff. Edward for relevant suggestions and very helpful criticism and to Dr Anne Field and Dr S. P. Lapage for additional advice. 


\section{REFERENCES}

Al-Aubaidi, J. M. \& Fabricant, J. (I97I). Characterization and classification of bovine Mycoplasma. Cornell Veterinarian 6r, 490-5 8.

Aluotto, B. B., Wittler, R. G., Williams, C. O. \& Faber, J. E. (i970). International Journal of Systematic Bacteriology 20, 35-58.

Anderson, D. R. (1969). Ultrastructural studies of mycoplasmas and the L-phase of bacteria. In The Mycoplasmatales and the L-Phase of Bacteria, chap. I2. Edited by L. Hayflick. New York: Appleton-CenturyCrofts.

ANDrEws, B. E. \& Kunze, M. (1972). Further observations on the value of polyanethol sulphonate for differentiating Acholeplasma and Mycoplasma species. (Abstract) Zeitschrift fïr Medizinische Mikrobiologie und Immunologie 157, 75.

Armstrong, D., Yu, B. H., Yagoda, A. \& Kagnoff, M. F. (197I). Colonization of humans by Mycoplasma canis. Journal of Infectious Diseases 124, 607-609.

Barile, M. F., Del Giudice, R. A., Carski, T. R., Gibbs, C. J. \& Morris, J. A. (i968). Isolation and characterization of Mycoplasma arginini spec. nov. Proceedings of the Society for Experimental Biology and Medicine r29, 489-494.

BARILE, M. F. \& KERN, J. (1971). Isolation of Mycoplasma arginini from commercial bovine sera and its implication in contaminated cell cultures. Proceedings of the Society for Experimental Biology and Medicine 138, 432-437.

Brookbanks, E. O., Carter, M. E. \& Holland, J. T. S. (I969). Mycoplasma mastitis. New Zealand Veterinary Journal 17, I 79-180.

Carstensen, E. L., Maniloff, J. \& Einolf, C. W. (I971). Electrical properties and ultrastructure of Mycoplasma membranes. Biophysical Journal II, 572-581.

Clyde, W. A. Jun. (I964). Mycoplasma species identification based upon growth inhibition by specific antisera. Journal of Immunology 92, 958-965.

Cole, B. C., Cahill, J. F., Wiley, B. B. \& Ward, J. R. (I969). Immunological responses of the rat to Mycoplasma arthritidis. Journal of Bacteriology 98, 930-937.

Cotrew, G. S. (1970). Mycoplasmas isolated from cattle in Australia. Australian Veterinary Journal 46, $378-381$.

CotTew, G. S. \& LeACH, R. H. (1969). Mycoplasmas of cattle, sheep and goats. In The Mycoplasmatales and the L-phase of Bacteria, chap. 19. Edited by L. Hayflick. New York: Appleton-Century-Crofts.

EDWARD, D. G. FF. E. (I954). The pleuropneumonia group of organisms: a review, together with some new observations. Journal of General Microbiology ro, 27-64.

EDWARD, D. G. FF. E. (1971). Determination of sterol requirement for Mycoplasmatales. Journal of General Microbiology 69, 205-210.

Edward, D. G. FF. \& Freundt, E. A. (1956). The classification and nomenclature of organisms of the pleuropneumonia group. Journal of General Microbiology 14, 197-207.

Edward, D. G. FF. \& Freundt, E. A. (I969). Classification of the Mycoplasmatales. In The Mycoplasmatales and the L-phase of Bacteria, chap. 5. Edited by L. Hayflick. New York: Appleton-Century-Crofts.

Edward, D. G. FF. \& Freundt, E. A. (1970). Amended nomenclature for strains related to Mycoplasma laidlawii. Journal of General Microbiology 62, I-2.

EDWARD, D. G. FF. \& FREUndT, E. A. ( I973). The type strains of species of Mycoplasmatales, including the designation of neotypes for Mycoplasma mycoides subsp. mycoides, Mycoplasma agalactiae subsp. agalactiae and Mycoplasma arthritidis. International Journal of Systematic Bacteriology (in the press).

EDWARD, D. G. FF. \& MOORE, W. B. ( I972). Determination of utilization of glucose by mycoplasmas. Second Conference on the Taxonomy and Physiology of Mycoplasmas. Brno, Czechoslovakia (in the press).

Ernø, H. \& Jurmanoví, K. (1972). Serological studies of bovine mycoplasmas (Abstract). Second Conference on the Taxonomy and Physiology of Mycoplasmas. Brno, Czechoslovakia (in the press).

ERnø, H. \& STIPKOVITS, L. (I 972). Cultural and biochemical studies of bovine mycoplasma species or serogroups (Abstract). Second Conference on the Taxonomy and Physiology of Mycoplasmas. Brno, Czechoslovakia (in the press).

Gourlay, R. N. (I 968 ). The isolation of T-strains of Mycoplasma from pneumonic calf lungs. Research in Veterinary Science $9,376-378$.

Gourlay, R. N. \& LEACH, R. H. (I970). A new mycoplasma species isolated from pneumonic lungs of calves (Mycoplasma dispar sp. nov.). Journal of Medical Microbiology 3, I I I-I 23. 
Gourlay, R. N., Mackenzie, A. \& Cooper, J. E. (1970). Studies on the microbiology and pathology of pneumonic lungs of calves. Journal of Comparative Pathology and Therapeutics 8o, 575-584.

Hale, H. H., Helmboldt, C. F., Plastridge, W. N. \& Stula, E. F. (ig62). Bovine mastitis caused by a Mycoplasma species. Cornell Veterinarian 52, 582-591.

HAYfLICK, L. (1965). Tissue cultures and mycoplasmas. Texas Reports on Biology and Medicine 23, 285-303 (Suppl. I).

Hirth, R. S., Plastridge, W. N. \& Tourtellotte, M. E. (1967). Survival of a Mycoplasma in frozen bovine semen. American Journal of Veterinary Research 28, 97-99.

HORNE, R. W. (1970). The ultrastructure of mycoplasma and mycoplasma-like organisms. Micron 2, 19-38.

Horváth, Z., Bokori, J., Stipkovits, L. \& Molnár, L. (197I). Mycoplasma - fertözöttség hazai elöfordulása bikákban (Mycoplasma infection in bulls). Magyar Allatorvosok Lapja 26, 51 I-516.

Hudson, J. R. \& ETHERIDGe, J. R. (1963). A new type of pleuropneumonia-like organism (PPLO) from the nose of cattle. Australian Veterinary Journal 39, I-5.

JAIN, N. C., JASPER, D. E. \& Dellinger, J. D. (1967). Cultural characters and serological relationships of some mycoplasmas isolated from bovine sources. Journal of General Microbiology 49, 40 I-4IO.

Klieneberger-Nobel, E. (1962). Pleuropneumonia-like Organisms (PPLO): Mycoplasmataceae. London and New York: Academic Press.

Kraybill, W. H. \& Crawford, Y. E. (1965). A selective medium and colour test for Mycoplasma pneumoniae. Proceedings of the Society for Experimental Biology and Medicine 1x8, 965-970.

Kunze, M. (1971). Natrium-Polyanethol-Sulphonat als diagnostisches Hilfsmittel bei der Differenzierung von Mycoplasmen. Zentralblatt fïr Bakteriologie, Parasitenkunde, Infektionskrankheiten und Hygiene. (Abteilung: I. Originale) 2x6, 50I-505.

LANGer, P. H. \& CARMiChaeL, L. E. (I963). Identification of pneumoenteritis isolates from cattle as Mycoplasma. Proceedings of the 67th Annual Meeting of the United States Livestock and Sanitary Association, pp. I29-I37.

LANGFORD, E. V. \& LEACH, R. H. (1973). Characterization of a mycoplasma isolated from infectious bovine keratoconjunctivitis: M. oculi: sp. nov. Canadian Journal of Microbiology (in the press).

LEACH, R. H. (1967). Comparative studies of mycoplasma of bovine origin. Annals of the New York Academy of Sciences 143, 305-316.

LEACH, R. H. (1970). The occurrence of Mycoplasma arginini in several animal hosts. Veterinary Record 87, 319-320.

LeMCKE, R. M. (1964). The serological differentiation of Mycoplasma strains (pleuropneumonia-like organisms) from various sources. Journal of Hygiene 62, 199-219.

MinuTes of the meeting (Ioth August 1970) of the Subcommittee on the Taxonomy of the Mycoplasmatales (1971). International Journal of Systematic Bucteriology 21, I5I-I 53.

Mollenhauer, H. H. (1964). Plastic embedding mixtures for use in electron microscopy. Stain Technology 39, III-II4.

Neimark, H. C. (1970). Division of mycoplasmas into subgroups. Journal of General Microbiology 63, 249-263.

Purcell, R. H., Taylor-Robinson, D., Wong, D. \& Chanock, R. M. (1966). A color test for the measurement of antibody to the non-acid-forming human mycoplasma species. American Journal of Epidemiology $84,5 \mathrm{I}-66$.

Razin, S. (1968). Mycoplasma taxonomy studied by electrophoresis of cell proteins. Journal of Bacteriology $96,687-694$.

Razin, S. (1969). Structure and function in mycoplasmas. Annual Review of Microbiology 23, 31 7-356.

Razin, S. \& Tully, J. G. (1970). Cholesterol requirement of mycoplasmas. Journal of Bacteriology roz, 306-3 I0.

Simmons, G. C. \& Johnston, L. A. Y. (1963). Arthritis in calves caused by Mycoplasma sp. Australian Veterinary Journal 39, I I-14.

Stipkovits, L., Bokori, J., Horváth, Z. \& Molnár, L. (I970). Incidence of bovine mycoplasma of group 6 in Hungary. Tenth Conference on Taxonomy of Bacteria and Mycoplasmas. Part 2. Brno, Czechoslovakia. (in the press).

Subcommittee on the Taxonomy of Mycoplasmatales (1972). Proposals for minimal standards for descriptions of new species of the order Mycoplasmatales. International Journal of Systematic Bacteriology 22, I $84-188$.

TAYlor-Robinson, D. \& Dinter, Z. (I968). Unexpected serotypes of mycoplasmas isolated from pigs. Journal of General Microbiology 53, 22 1-229. 
Taylor-Robinson, D., Martin-Bourgon, C., Wanatabe, T. \& Addey, J. P. (1971). The isolation of Tmycoplasmas from dogs and squirrel monkeys: biological and serological comparison with those isolated from man and cattle. Journal of General Microbiology 68, 97-107.

Taylor-Robinson, D., Purcell, R. H., Wong, D. C. \& Chanock, R. M. (1966). A colour test for the measurement of antibody to certain mycoplasma species based upon the inhibition of acid production. Journal of Hygiene 64, 91-104.

Taylor-Robinson, D., Thomas, M. \& Dawson, P. L. (1969). The isolation of T-mycoplasmas from the urogenital tract of bulls. Journal of Medical Microbiology 2, 527-533.

Taylor-Robinson, D., Williams, M. H. \& Haig, D. A. (I968). The isolation and comparative biological and physical characteristics of T-mycoplasmas of cattle. Journal of General Microbiology 54, 33-46.

Tully, J. G., Del Giudice, R. A. \& Barile, M. F. (1972). Synonomy of Mycoplasma arginini and Mycoplasma leonis. International Journal of Systematic Bacteriology 22, 47-49.

Tully, J. G. \& RAZIN, S. (I968). Physiological and serological comparisons among strains of Mycoplasma granularum and Mycoplasma laidlawii. Journal of Bacteriology 95, I 504-15I 2.

Tully, J. G. \& RAZIN, S. (1970). Acholeplasma axanthum, sp.n.: a new sterol-nonrequiring member of the Mycoplasmatales. Journal of Bacteriology 103, 75I-754.

Zola, H., Baxendale, W. \& Sayer, L. J. (1970). Polyacrylamide gel electrophoresis of lysates of mycoplasmas. Research in Veterinary Science II, 397-400. 